Final Report

FHWA/IN/JTRP-2004/8

\title{
LIFE AND COST COMPARISON OF THREE REHABILITATION TECHNIQUES ON I-65 BETWEEN SR-2 AND SR-114
}

\author{
By \\ Sedat Gulen, PE \\ Principal Investigator \\ Statistical Consultant \\ John Weaver, PE \\ Planning Engineer \\ Environmental, Planning \& Engineering Division \\ Indiana Department of Transportation \\ Samy Noureldin, Ph.D., PE \\ Section Manager \\ Research Division \\ Indiana Department of Transportation \\ Joint Transportation Research Program \\ Project No. C-36-46BB \\ File No. 5-11-28 \\ HPR-2064
}

The contents of this report reflect the views of the authors who are responsible for the facts and the accuracy of the data presented. The contents do not necessarily reflect views or policies of the Federal Highway Administration and the Indiana Department of Transportation. This report does not constitute a standard, specification or regulation.

\author{
Indiana Department of Transportation \\ Research Division \\ June 2004
}




\begin{tabular}{|c|c|c|c|c|}
\hline $\begin{array}{l}\text { 1. Report No. } \\
\text { FHWA/IN/JTRP-2004/8 }\end{array}$ & \multicolumn{2}{|c|}{ 2. Government Accession No. } & \multicolumn{2}{|c|}{ 3. Recipient's Catalog No. } \\
\hline \multirow{2}{*}{\multicolumn{3}{|c|}{$\begin{array}{l}\text { 4. Title and Subtitle } \\
\text { Life and Cost Comparison of three Rehabilitation Techniques on I-65 Between SR-2 } \\
\text { And SR-114 }\end{array}$}} & \multicolumn{2}{|l|}{$\begin{array}{l}\text { 5. Report Date } \\
\text { June } 2004\end{array}$} \\
\hline & & & \multicolumn{2}{|c|}{ 6. Performing Organization Code } \\
\hline \multirow{2}{*}{\multicolumn{3}{|c|}{$\begin{array}{l}\text { 9. Performing Organization Name and Address } \\
\text { Joint Transportation Research Program } \\
\text { Indiana Department of Transportation , Research Division } \\
\text { P.O. Box } 2279 \\
\text { West Lafayette, IN } 47906\end{array}$}} & \multicolumn{2}{|l|}{ 10. Work Unit No. } \\
\hline & & & \multicolumn{2}{|c|}{$\begin{array}{c}\text { 11. Contract or Grant No. } \\
\text { HPR-2064 }\end{array}$} \\
\hline \multicolumn{2}{|l|}{$\begin{array}{l}\text { 12. Sponsoring Agency Name and Address } \\
\text { Indiana Department of Transportation } \\
\text { State Office Building } \\
100 \text { North Senate Avenue } \\
\text { Indianapolis, IN } 46204\end{array}$} & & \multicolumn{2}{|c|}{$\begin{array}{l}\text { 13. Type of Report and Period Covered } \\
\text { Final report } \\
\text { 14 }\end{array}$} \\
\hline \multicolumn{5}{|c|}{$\begin{array}{l}\text { 15. Supplementary Notes } \\
\text { Prepared in cooperation with the Indiana Department of Transportation and Federal Highway Administration }\end{array}$} \\
\hline \multicolumn{5}{|c|}{$\begin{array}{l}\text { 1. Abstract } \\
\text { Construction of hot mix asphalt (HMA) overlays on top of old concrete pavements is the most common concrete pavement reh } \\
\text { strategy. These overlays, however, are usually subject to reflection cracking related to the movement of the old concrete slab. In } \\
\text { these overlays may also be vulnerable to rutting when subjected to large traffic volumes of heavy trucks. Concrete overlays } \\
\text { advantage of being rut resistant compared to HMA overlays. However, the current national experience of the performance } \\
\text { overlays is still, relatively, limited compared to HMA overlays. In addition, doubts are often raised about the cost effectivenes } \\
\text { overlays, the ease of their rehabilitation at the end of their design life and the period of time required closing the road to traffic fo } \\
\text { and post construction operations. } \\
\text { This report presents an evaluation of three concrete pavement rehabilitation techniques employed on interstate highway I- } 65 \text {; } \\
\text { - A fiber modified HMA overlay on cracked and seated concrete pavement, } \\
\text { - An HMA overlay on rubblized concrete pavement, and } \\
\text { - An unbonded concrete overlay on } 30 \mathrm{~mm} \text { intermediate HMA layer on old concrete pavement. }\end{array}$} \\
\hline \multirow{2}{*}{\multicolumn{5}{|c|}{$\begin{array}{l}\text { Evaluation of these techniques will continue till the year } 2013 \text { by the Research Division Staff. Performance of these rehabilitation } \\
\text { techniques is also compared with that of restoration (no overlay) techniques applied in } 1985 \text { on the same highway segment. } \\
\text { It was concluded that all rehabilitation techniques performed satisfactorily. "Unbonded concrete overlay" segment exhibited the best } \\
\text { performance in reflection cracks elimination, structural capacity and skid resistance. "Rubblized" segment exhibited the best performance } \\
\text { in ride quality and uniformity of structural capacity. } \\
\text { Life cycle cost analysis without road user costs suggested that the "unbonded concrete overlay" was slightly more cost-effective than the } \\
\text { other segments. }\end{array}$}} \\
\hline & & & & \\
\hline \multicolumn{2}{|c|}{$\begin{array}{l}\text { 17. Key Words } \\
\text { Concrete Pavement Rehabilitation, Rubblization, Cracking and Seating, } \\
\text { Unbonded Concrete Pavement, Concrete Pavement Restoration, Life } \\
\text { Cycle Cost analysis }\end{array}$} & \multicolumn{3}{|c|}{$\begin{array}{l}\text { 18. Distribution Statement } \\
\text { No Restrictions. This document is available to the public } \\
\text { through National Technical Information }\end{array}$} \\
\hline 19. Security Classification (of this report) & $\begin{array}{r}\text { 20. Security Classif } \\
\text { Uncla }\end{array}$ & $\begin{array}{l}\text { (of this page) } \\
\text { sified }\end{array}$ & 21. No. of Pages & 22. Price \\
\hline
\end{tabular}

Form DOT F 1700.7 (8-69) 


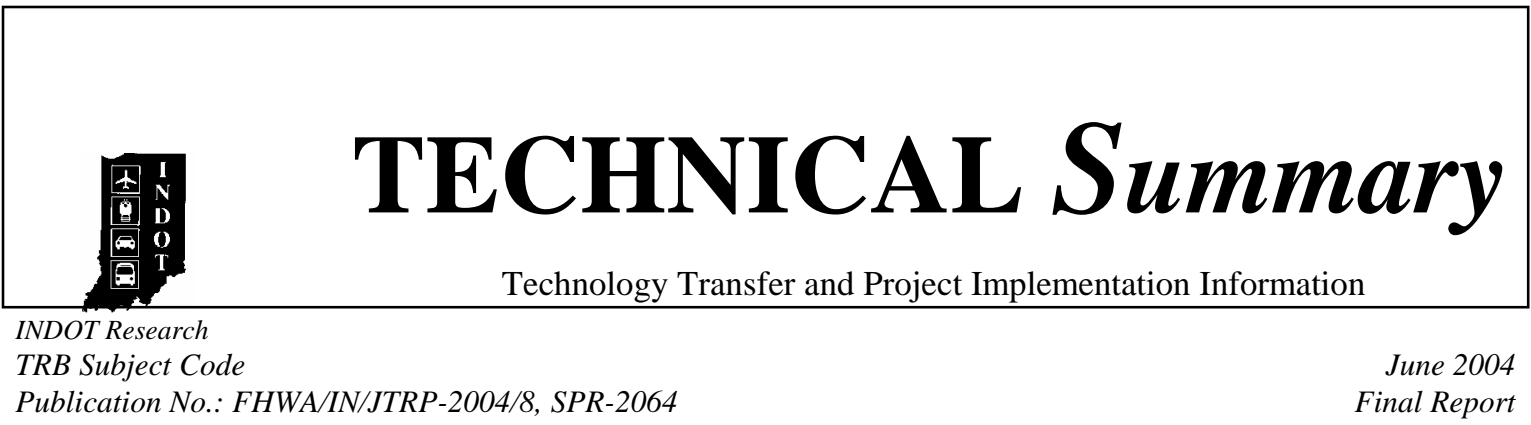

\section{LIFE AND COST COMPARISON OF THREE REHABILITATION TECHNIQUES ON I-65 BETWEEN SR-2 AND SR-114}

\section{Introduction}

The Indiana Department of Transportation is increasingly committed to the rehabilitation of the pavement network in the State of Indiana. A number of rehabilitation techniques are in current use, each with an associated construction cost per lane-mile. While the condition of the existing pavement may, to some extent, dictate an appropriate method, in the majority of cases more than one method could be used.

Construction of hot mix asphalt (HMA) overlays on top of old concrete pavements is the most common concrete pavement rehabilitation strategy for Indiana highway network. These overlays, however, are usually subject to reflection cracks, which significantly reduce pavement serviceability at a rapid rate. Old practice suggests that the period of time in years for reflection cracks appearance on such overlays is approximately 1.5 times its thickness in inches (6 years for a 4 inches overlay).

Reflection cracks are those transverse cracks appearing on an HMA overlay at the exact location of concrete joints and midslab cracks in accordance with the following mechanism: tensile strains at the bottom of the HMA overlay with large intensity at the locations of concrete joints and midslab cracks.

- Transverse hair cracks are initiated as a result of these tensile strains.

- Differential vertical deflections of concrete pavement at the locations of joints and midslab cracks cause the propagation of those hair cracks to pavement surface in the form of transverse cracks called reflection cracks.

Several concrete pavement rehabilitation strategies are currently available to minimize, delay or eliminate reflection cracks. These strategies are based on disrupting the mechanism described above and include;

- Employing only concrete pavement restoration (CPR) techniques without using any HMA overlay.

- Employing cracking (or breaking) and seating technique for concrete slab reduction prior to constructing the HMA overlay.

- Rubblizing the concrete slab to reduce it to a granular base prior to constructing the HMA overlay.

- Using a concrete overlay (bonded or unbonded) instead of an HMA overlay.

- Expansion and contraction of concrete pavement and traffic loads produce horizontal

\section{Findings}

The following conclusion and recommendations were made based on the basis of this study

1. Unbonded concrete overlay is a very effective rehabilitation technique for eliminating reflection cracks. 
2. Rubblization is an effective rehabilitation technique for minimizing and delaying reflection cracks if constructed successfully.

3. The 1993 cracking and seating technique (as used here on I-65) is not recommended. This technique has already been improved.

4. Annual visual condition surveys suggest that "concrete" segment has better performance than the "rubblized" and "cracking and seating” segments.

5. Annual ride quality and skid resistance values of all overlays are statistically equal.

6. Annual FWD deflection measurements suggest that "concrete" segment has lower deflection compared to the "rubblized" and “cracking and seating” segments.
7. Structural design employed herein for "concrete" and "rubblized" segments appear to be in the conservative side.

8. Life cycle cost analysis suggests that "concrete" segment is the most cost effective followed by "rubblized" and "cracking and seating" segments, respectively. However, this is (as explained in the text of the report) a very close call.

9. Visual inspections of the three overlay techniques in the last 5 years indicated that there are visible cracks in the "Rubblized" and "Cracking and seating" segments and they were scheduled for crack sealing operations and sealed in the 2000 construction season. The costs of these operations $(\$ 17,200.00$ per mile) will be added to the life cycle costs of those two overlays at the implementation stage.

\section{Implementation}

Based on this long term research study, the findings and recommendations are to be implemented: The Materials and Tests Division and the Research Division of INDOT should implement the findings and recommendations of this report.

1. Unbonded concrete overlays are viable rehabilitation techniques which should be employed on appropriate highway sections.

2. Annual field inspection is strongly recommended since this is a long term research study (as per the Chief Highway Engineer). An evaluation period of 20 years after construction is recommended. A more meaningful lifecycle cost may be assessed to each section at that time. The authors of this report preferred 6 years data points, as officially approved before, for the IRI in order to improve the performance predictions for accurate life cycle cost analyses. However, majority of SAC members recommended that the study be discontinued.

3. Annual visual inspection should be made along with the IRI and Friction data should also be obtained employing the Research Division's equipment and staff.

4. Rubblized treatment is preferred over Crack \& Seated treatment.

5. Joint sealing of Unbonded Concrete Segments need to be implemented. 


\section{Contact}

For more information:

Sedat Gulen

Principal Investigator

3600 North Ocean Drive Apt. 301

Singer Island, FL 33404

Phone: (561) 845-8410

sedatg@highstream.net

Samy Noureldin

Project Administrator

Division of Research

1205 Montgomery Street

P.O. Box 2279

West Lafayette, IN 47906

Phone: (765) 463-1521

Fax: (765) 497-1665

snoureldin@indot.state.in.us
Indiana Department of Transportation

Division of Research

1205 Montgomery Street

P.O. Box 2279

West Lafayette, IN 47906

Phone: (765) 463-1521

Fax: (765) 497-1665

\section{Purdue University}

Joint Transportation Research Program

School of Civil Engineering

West Lafayette, IN 47907-1284

Phone: (765) 494-9310

Fax: (765) 496-7996 


\section{ACKNOWLEDGEMENTS}

The authors hereby wish to thank Mr. Dave Andrewski, the Materials Engineer of the Materials and Tests Division of Indiana Department of Transportation (INDOT), who originally designed and initiated this useful research project for INDOT. The authors acknowledge the constant support provided by Dr. Partridge of INDOT Research Division. We also appreciate the valuable support and data collection by Shuo Li, Khaled Galal, Thomas Williams, Gordon Hooker, Larry Bateman and David Hinshaw of INDOT Research Division throughout the execution of the study.

The authors also wish to thank Mr. Richard Smutzer, Chief Highway Engineer of INDOT, for his participation in this research study as a SAC member and support throughout the execution of the study. The authors acknowledge support and participation by the study advisory committee members (SAC), Lee Gallivan of FHWA, Williams Flora of INDOT and Gerry Huber of Heritage Research Foundation.

We are also grateful to the JTRP coordinator, Karen Hatke, for the important role she played throughout the course of this project. 
TABLE OF CONTENTS

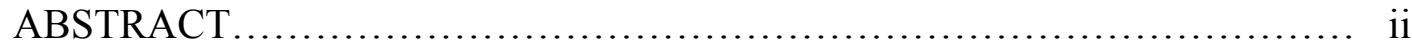

LIST OF TABLES...................................................... vi

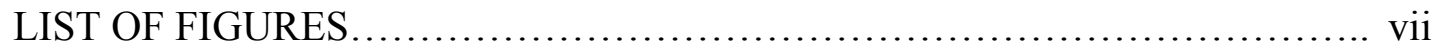

I. INTRODUCTION............................................ 1

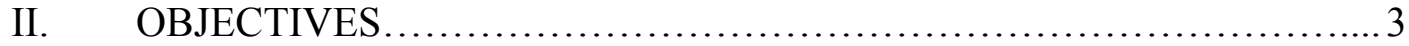

III. PAVEMENT CONDITION HISTORY .................................4

Description of Pavement segment.............................4

Pavement Condition in 1985....................................4

Visual................................................. 4

Ride Quality \& serviceability.............................4

Friction Numbers.......................................4

Deflection....................................... 7

Concrete Pavement Restoration Techniques Applied in 1985 ..... 7

Undersealing............................................ 7

Patching............................................ 7

Routing \& resealing................................... 7

Diamond grinding.................................. 7

Performance of CPR Techniques ........................... 8

Visual................................................. 8

Ride Quality \& Serviceability.......................... 8

Deflection............................................ 8

IV. MAJOR REHABILITATION TECHNOQUES APPLIED .................11

Construction................................................ 11

Fiber modified HMA over cracked \& seated JRCP....... 11

HMA over rubblized JRPC..............................13

Unbonded concrete overlay over JRCP...................13

V. PERFORMANVE OF REHABILITATION TECHNOQUES (1994-2003) 13

Traffic Count..................................... 13

Visual............................................... 14

Ride quality ............................................... 16

Friction Numbers.....................................18

Deflection....................................... 20

Uniformity of pavement performance parameters....... 20

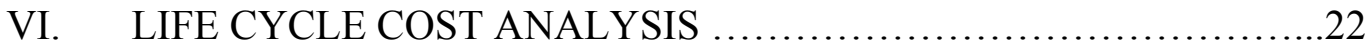


Page

VII. FINDINGS AND CONCLUSIONS ............................ 25

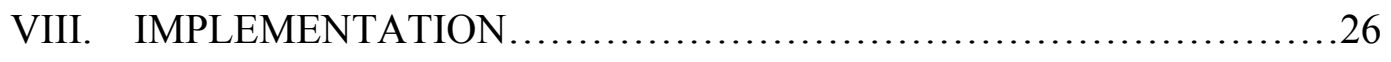

LIST OF REFERENCES ........................................ 27 


\section{LIST OF TABLES}

Table

Page

Table 1: $\quad$ Traffic Parameters of I-65 Outer lane........................... 14

Table 2: $\quad$ Uniformity of Pavement Evaluation Parameters................... 21

Table 3: Construction Cost Data of the Three Rehabilitation Techniques

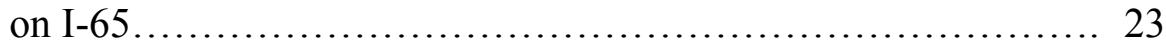

Table 4: $\quad$ Present Worth of Costs of Various Concrete Pavements Rehabilitation Strategies ......................................24 


\section{LIST OF FIGURES}

Figure $\quad$ Page

Figure 1: $\quad$ Reflection Crack on an HMA Overlay....................... 2

Figure 2: $\quad$ Major Distress Noted on I-65 Segment under Study in 1985....... 5

Figure 3: $\quad$ I-65 Serviceability from 1968 to $1985 \ldots \ldots \ldots \ldots \ldots \ldots \ldots \ldots \ldots$

Figure 4: $\quad$ Distresses Associated with Partial Depth Patches.............. 9

Figure 5: $\quad$ I-65 Serviceability from 1985 to $1993 / 1994 \ldots \ldots \ldots \ldots \ldots \ldots \ldots \ldots$

Figure6: $\quad$ Layout of Concrete Pavement Rehabilitation Sections on I-65... 12

Figure 7: $\quad$ Raveling and Polishing Signs on "Cracked \& Seated" and "Rubblized" Sections........................................ 14

Figure 8: $\quad$ Full Width Transverse Cracks on "Cracked \& Seated" and "Rubblized" Sections....................................... 15

Figure9: $\quad$ IRI values on I-65 rehabilitation sections from 1994 to $2003 \ldots \ldots \quad 16$

Figure 10: $\quad$ IRI Values on I-65 from rehabilitation sections 2000 to $2003 \ldots \ldots 17$

Figure 11: I-65 Friction Numbers from 1995 to $2003 \ldots \ldots \ldots \ldots \ldots \ldots \ldots$

Figure 12: $\quad$ Concrete Surface Texture................................. 19

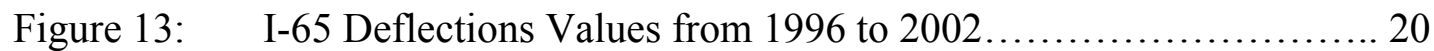




\section{INTRODUCTION}

The Indiana Department of Transportation is increasingly committed to the rehabilitation of the pavement network in the State of Indiana. A number of rehabilitation techniques are in current use, each with an associated construction cost per lane-mile. While the condition of the existing pavement may, to some extent, dictate an appropriate method, in the majority of cases more than one method could be used.

Construction of hot mix asphalt (HMA) overlays on old concrete pavements is the most common concrete pavement rehabilitation strategy for Indiana highway network. These overlays are sometimes subject to reflection cracks, which significantly reduce pavement serviceability at a rapid rate. Old practice suggests that the period of time in years for reflection cracks appearance on such overlays is approximately 1.5 times its thickness in inches (6 years for a 4 inches overlay).

Reflection cracks are those transverse cracks appearing on an HMA overlay at the exact location of concrete joints and midslab cracks (Figure 1) in accordance with the following mechanism:

- Expansion and contraction of concrete pavement and traffic loads produce horizontal tensile strains at the bottom of the HMA overlay with large intensity at the locations of concrete joints and midslab cracks.

- Transverse hair cracks are initiated as a result of these tensile strains.

- Differential vertical deflections of concrete pavement at the locations of joints and midslab cracks cause the propagation of those hair cracks to pavement surface in the form of transverse cracks called reflection cracks.

Several concrete pavement rehabilitation strategies are available to minimize, delay or eliminate reflection cracks $(1-3)$. These strategies are based on disrupting the mechanism described above and include;

- Employing only concrete pavement restoration (CPR) techniques without using any HMA overlay $(4-6)$.

- Employing cracking (or breaking) and seating technique for concrete slab reduction prior to constructing the HMA overlay (7).

- Rubblizing the concrete slab to reduce it to a granular base prior to constructing the HMA overlay.

- Using a concrete overlay (bonded or unbonded) instead of an HMA overlay. 

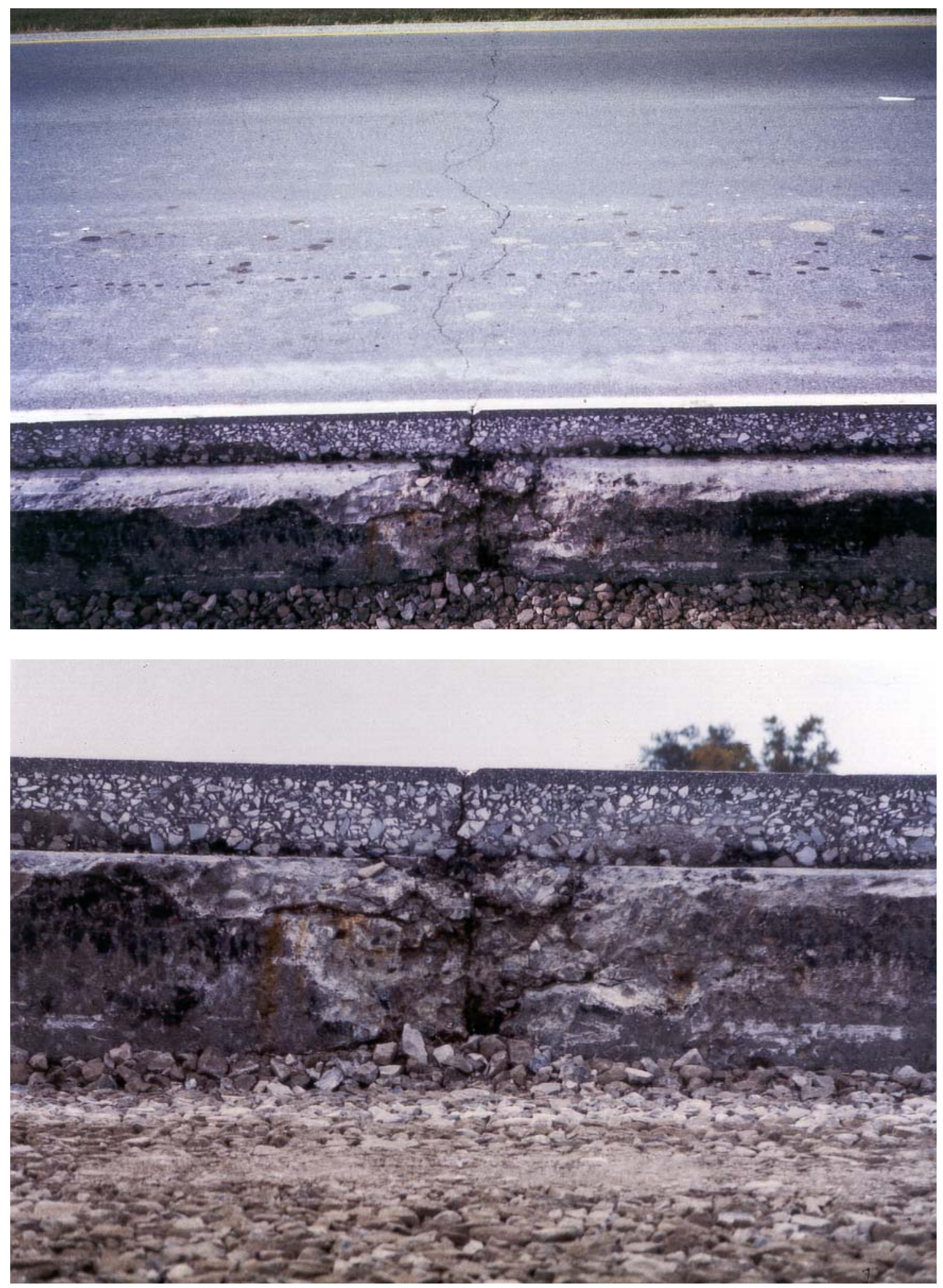

Figure 1: Reflection Crack on an HMA Overlay 


\section{OBJECTIVES}

The main objectives of the study presented in this report are:

To evaluate the performance of three concrete pavement rehabilitation strategies on interstate highway I - 65;

a) Unbonded concrete overlay over the existing old concrete pavement. The depth of the overlay is $305 \mathrm{~mm}$ (12.0 in) at the centerline. 30-mm (1.25 inch) open graded HMA layer was placed between the overlay and existing concrete pavement.

b) HMA overlay, $330 \mathrm{~mm}$ (13 in.) in depth, over the rubblized existing old concrete pavement.

c) Fiber-Reinforced HMA Overlay, $190 \mathrm{~mm}$. (7.5 in.) in depth, over the cracked and seated existing PCC pavement.

These thicknesses were verified by cores

Life cycle costs analyses of these strategies were also compared with that Concrete Pavement Restoration (CPR) techniques applied at a previous date on the same highway segment in 1985. 


\section{PAVEMENT CONDITION HISTORY}

\section{Description of Pavement Segment}

The pavement segment under consideration is the portion of the 4 lane divided interstate I - 65 between reference posts 217.2 and 237.8 (20.6 miles or $33 \mathrm{~km})$ on both north and south bound directions. This segment was constructed in 1968 as a jointed reinforced concrete pavement (JRCP). It consisted of a $254 \mathrm{~mm}$ (10 inches) reinforced concrete slab over a $203 \mathrm{~mm}$ (8 inches) sandy subbase. Slab length was $12.2 \mathrm{~m}$ (40 feet) and slab width was $3.7 \mathrm{~m}$ (12 feet) (6).

\section{$\underline{\text { Pavement Condition in } \mathbf{1 9 8 5}}$}

\section{Visual}

The pavement was sustaining 3000 trucks per day per direction of travel. Visual defects were present on 550 slabs of the outer lane and 43 slabs of the inner lane of the south bound (SB) direction and 533 slabs of the outer lane and 37 slabs of the inner lane of the north bound (NB) direction. Major distress types noted were medium to high severity midslab transverse cracks, corner breaks, faulted and broken up joints and some other minor surface imperfections (6),(Figure 2).

\section{Ride quality \& serviceability}

Ride quality was measured using a response type roughness measuring system, which was typically used by Indiana Department of Transportation (INDOT), during the 1980's(6). These ride quality measurements were normalized to predicted serviceability indices employing the equation reported by Trezos and Gulen (8). These predicted serviceability indices (PSI) corresponding to the measured roughness were 2.75 and 2.59 for the NB and SB directions, respectively. Average serviceability of the segment in 1985 was 2.67 , Figure 3 . Serviceability indices were marginally above 2.5 indicating the need for pavement rehabilitation.

\section{Friction Numbers}

Friction numbers were measured employing the method described in ASTM E-274 employing a ribbed tire. Average friction numbers for the NB and SB directions were 31 and 29, respectively (6). These numbers corresponds to coefficients of wet pavement friction of 0.31 and 0.29 , respectively. Average friction number of the segment in 1985 was 30 . These values were marginally above 28 (flag friction value when measuring friction using ribbed tire) indicating the need for pavement surface treatment. 

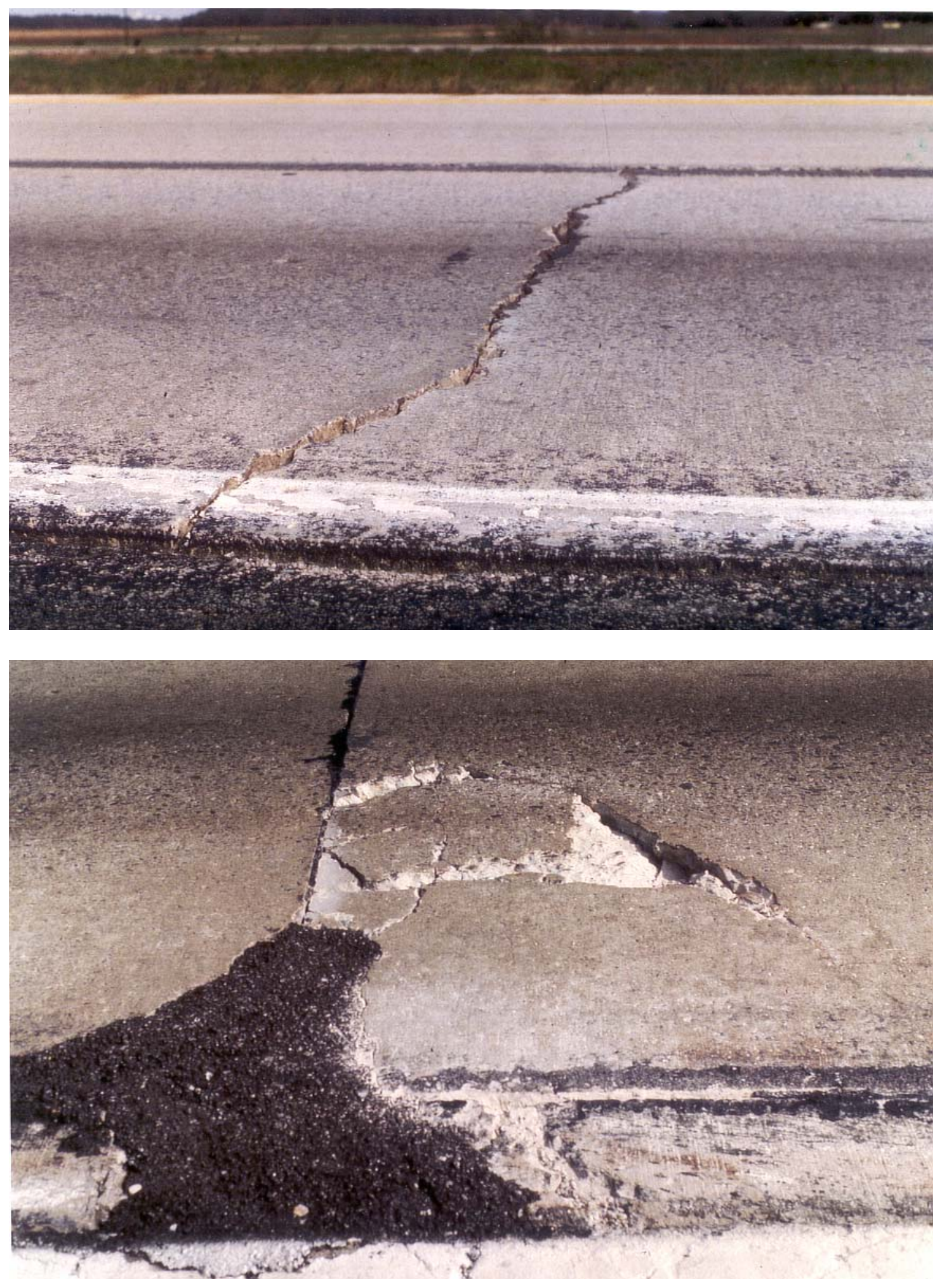

Figure 2: Major Distresses Noted on I - 65 Segments under Study in 1985 


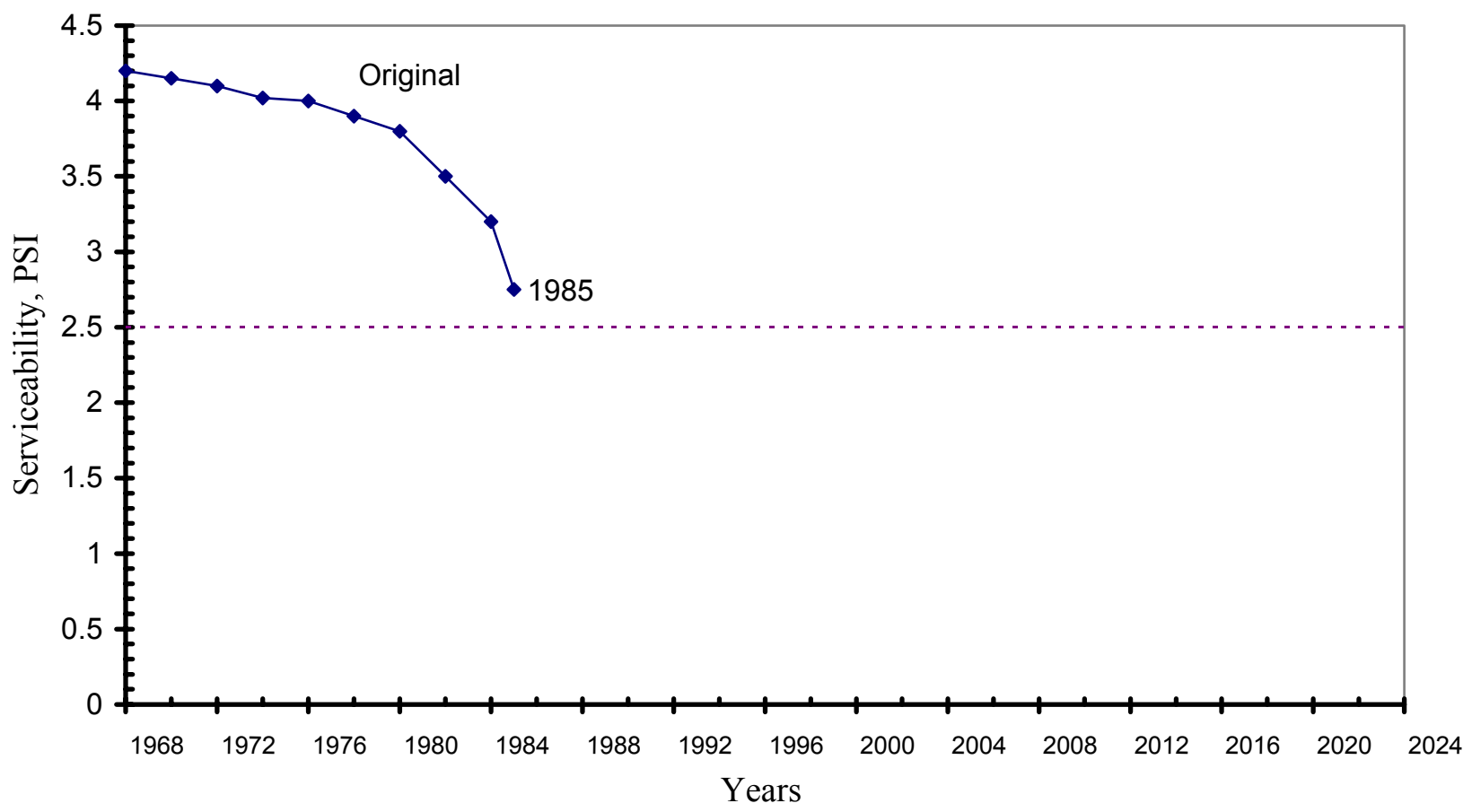

Figure 3: I - 65 Serviceability from 1968 to 1985 


\section{Deflection}

Structural capacity measurements were obtained employing the Dynaflect, which was typically used by INDOT at that time for evaluating structural capacity. Larger deflection values were obtained at the joints and midslab cracks than at non-cracked midslab points (6) indicating low load transfer. Dynaflect deflection values were considered at that time indicative of marginal structural capacity and a need for rehabilitation (6).

\section{Concrete Pavement Restoration Techniques Applied in 1985}

Concrete pavement restoration (CPR) techniques were employed (by the end of summer in 1985) on the segment described above to be compared with HMA overlays which were typically used in Indiana, as well as other States, during that period of time for concrete pavement rehabilitation purposes. The life cycle cost of CPR techniques was reported to be competitive with that of an asphalt overlay $(4,6)$.

\section{Undersealing}

Hot hard grade asphalt underseals were used to improve uniformity of concrete slab supporting conditions and reduce faulting at joints and midslab cracks. Underseal locations were determined employing the dynaflect (6).

\section{Patching}

Full depth concrete patches were used to replace sections of severe pavement breakups, for midslab repairs, and at severely broken up joints and cracks. Partial depth patches were used to repair minor surface distresses, slab corner breaks and other surface imperfections.

\section{Routing \& resealing}

Joints and midslab cracks were routed and resealed to inhibit intrusion of surface water and to avoid pumping resulting from surface water penetration (6).

\section{Diamond grinding}

Diamond grinding was employed on the entire segment after all construction activities were completed. This technique was used to obtain a smoother riding quality, eliminate minor faulting at joints and cracks and improve friction values (6). 


\section{Performance of CPR Techniques}

\section{Visual}

Numerous routed and resealed cracks and joints exhibited gradual faulting down in the direction of traffic. Hairline cracks had developed around them and eventually caused spalling. Some full depth patches also exhibited faulting at the last joint in traffic direction. Partial depth patches placed adjacent to joints and midslab cracks were spalling and broken up (Figure 4). Those placed over a crack had cracked (Figure 4). Furthermore, some partial depth patches were responsible for creating midslab cracks (Figure 4). Annual repairs were required for those patches and they where either replaced by full depth concrete patches or partial depth asphalt patches.

\section{Ride quality \& serviceability}

Figure 5, shows the combined average serviceability for the outer truck lane for both NB and SB directions before employing CPR, after employing CPR and annually thereafter to the year 1988 and then in the year 1994. Serviceability was estimated employing ride quality (or roughness) measurements and the equation reported by Trezos and Gulen (8). It was concluded that CPR techniques were very successful in improving ride quality as indicated by the serviceability values shown in Figure 5. However, progress of serviceability loss indicated that another major rehabilitation might be required by the year 1994.

\section{Deflection}

Average deflection values for the outer truck lane for both NB and SB directions were measured annually from the year 1985 to the year 1988 and then they were measured in the year 1994. It was concluded that CPR techniques were somewhat successful in improving the structural capacity as suggested by the modest reduction in deflection values. However, the progress of deflection increase indicated that another major rehabilitation would be required by the year 1994(6). 

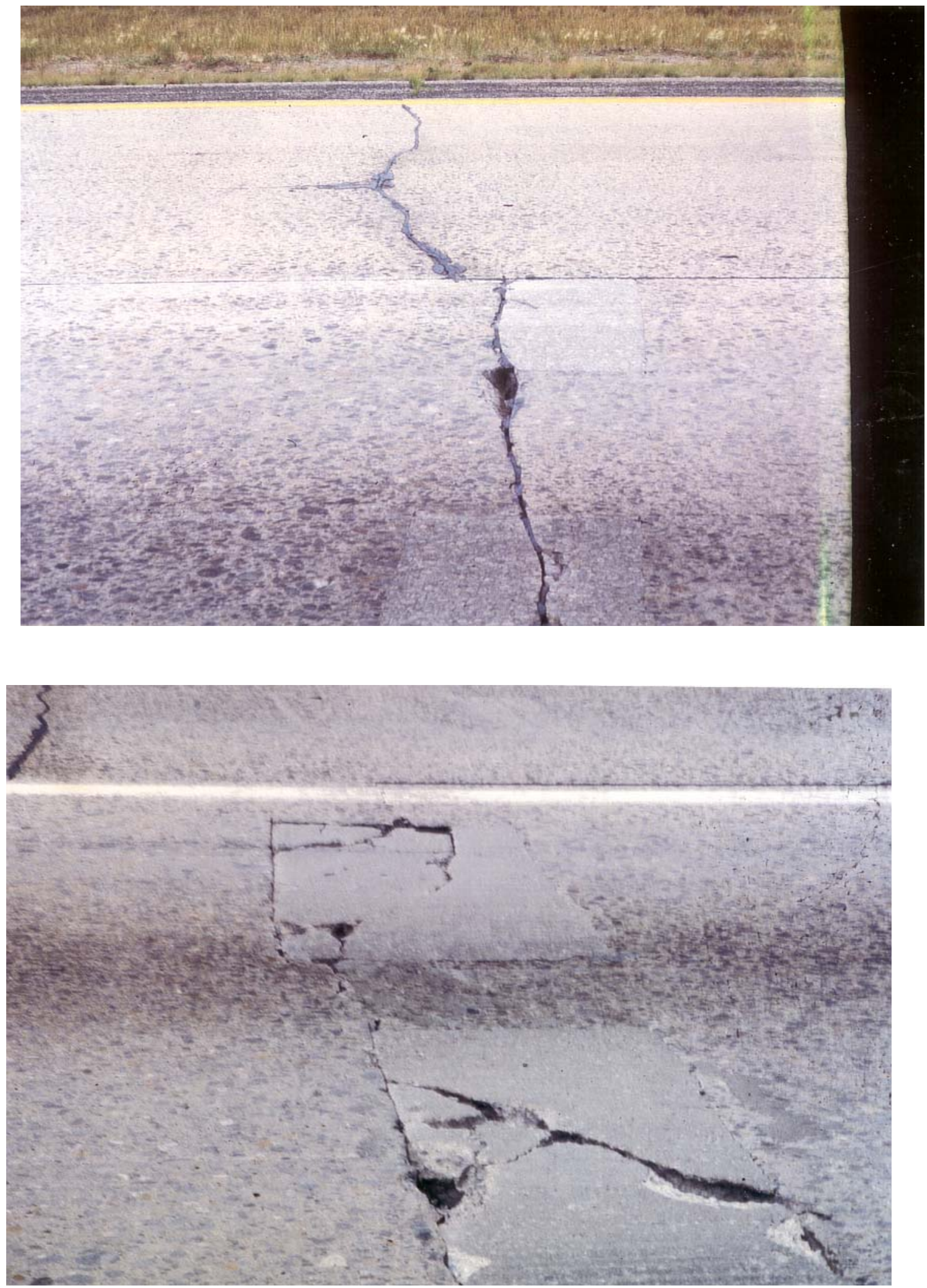

Figure 4: Distresses Associated with Partial Depth Patches 


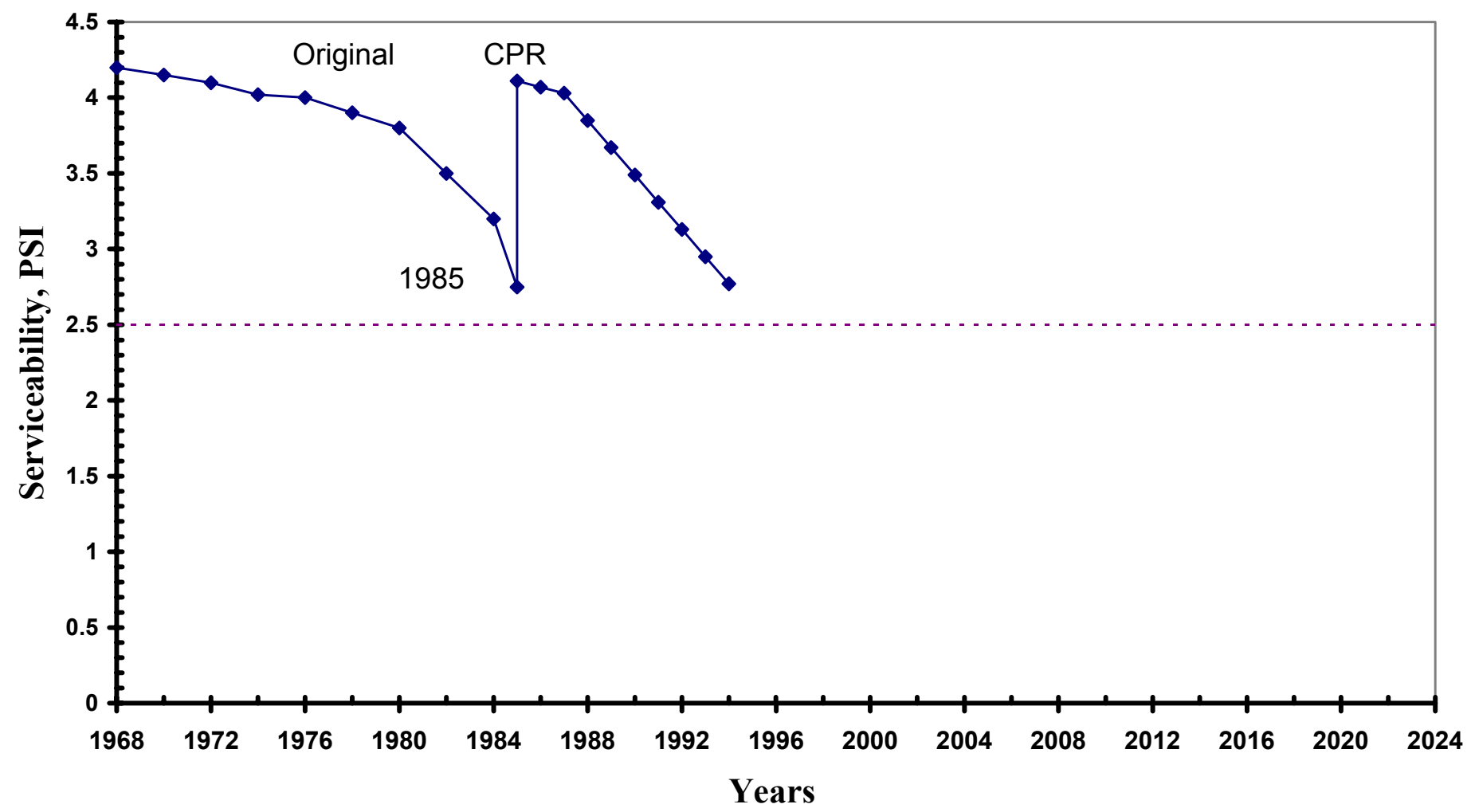

Figure 5: I - 65 Serviceability from 1985 to $1993 / 1994$

Note: Intermediate data points between 1968-1985 and 1989-1994 are estimated. The others are based on actual average field data. 


\section{MAJOR REHABILITATION TECHNIQUES APPLIED}

The following three rehabilitation techniques were employed for rehabilitation of I - 65 pavement segments during the year 1993/1994, (Figure 6):

- Fiber modified HMA overlay the cracked and seated existing old concrete pavement ( 8.7 miles or $13.9 \mathrm{~km}$ ),

- HMA overlay on the rubblized existing old concrete pavement (5.7 miles or 9.1 $\mathrm{km})$, and

- Unbonded concrete overlay on $30 \mathrm{~mm}$ intermediate HMA layer on the existing old concrete pavement (6.2 miles or $9.9 \mathrm{~km})$.

\section{Construction}

Fiber modified HMA over cracked \& seated JRCP (from RP 237.8 to RP 229.1)

Existing concrete pavement was cracked employing an impact drop hammer capable of producing full depth hairline transverse cracks at a nominal longitudinal spacing of 750 $\mathrm{mm}$ or less. A $40 \mathrm{~m}$ long by lane width check section was used to examine and ensure that a satisfactory cracking pattern is obtained. Water and sometimes flour were used to enhance the visual determination of cracking pattern.

The complete width of the cracked pavement was seated employing a 50 tons roller with 4 pneumatic tires (3 passes). All depression locations resulting from cracking and/or seating were filled using unbound aggregate material. The finished surface appeared satisfactory. However, it was not clear how to quantify the effect cracking pattern or the degree of compaction on the resulting quality of construction. A Falling Weight Deflectometer (FWD) was employed to monitor the quality of the cracking and seating operation. The finished surface was later swept and a tack coat was applied before the overlay.

Fiber modified HMA layer (containing $0.3 \%$ of $10 \mathrm{~mm}$ long Polypropylene fibers by weight of asphalt mix) was constructed in successive lifts.

The pavement cross section at the centerline consisted of $190 \mathrm{~mm}$ (7.5 inches) of fiber modified HMA overlay the cracked and seated existing old concrete pavement. 


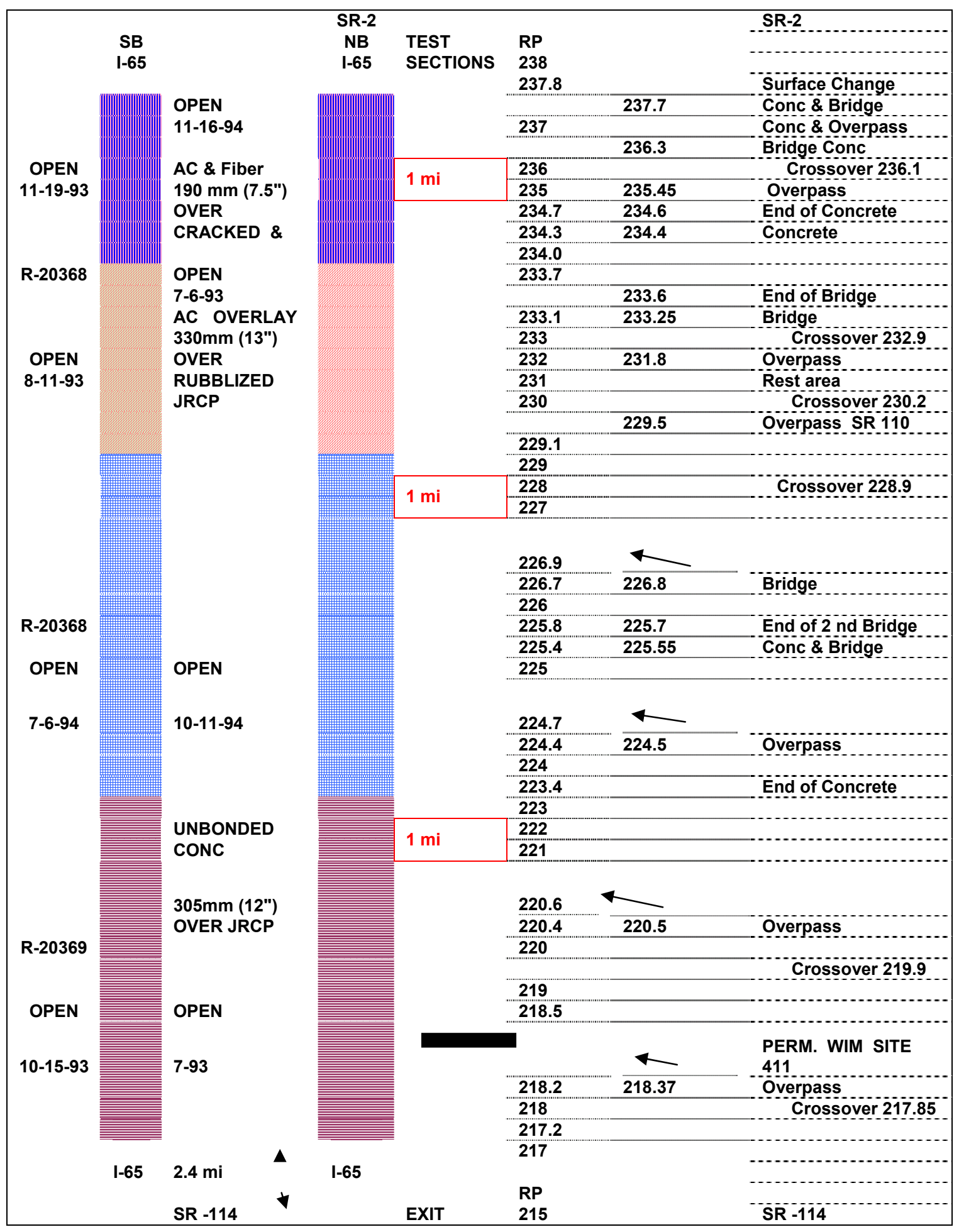

Figure 6: Layout of the 1993/1994 Rehabilitation Sections on I-65 


\section{PERFORMANCE OF REHABILTATION TECHNIQUES (1994--2003)}

\section{Traffic Count}

A weigh in motion (WIM) unit was installed in both at (RP 218.4) to provide information about traffic parameters including average daily traffic (ADT), percent trucks and truck weights. WIM data indicated that dominant truck type using I - 65 segment under study is Class 9 (5-axle semi) which consists of a single axle on single tires followed by two tandem axles and has an allowable gross weight of $356 \mathrm{KN}$. Table 1 presents the traffic parameters of I - 65 outer lane for 3 years. The WIM unit was taken out of service in 1999. 
Table 1: Traffic Parameters of I - 65 Outer Lane Year

\begin{tabular}{|l|c|c|c|}
\hline \multicolumn{1}{|c|}{ Traffic Parameters } & 1996 & 1997 & 1998 \\
\hline Average Daily Traffic & 8172 & 8002 & 9380 \\
\hline Percent Trucks & $25 \%$ & $28.4 \%$ & $28.7 \%$ \\
\hline Average Gross Weight (KN) & 221 & 236 & 260 \\
\hline
\end{tabular}

\section{Visual}

Concrete overlay section did not exhibit noticeable signs of distress thus far. HMA overlay on rubblized section and Fiber modified HMA on cracked and seated section show signs of weathering and raveling. These signs appeared in 1996 and became more pronounced in 1998. Raveling intensity is slightly more for "rubblized" section compared to "cracked and seated" section. Aggregates of raveled surface have started to show signs of polishing (Figure 7). Low to medium severity full width transverse cracks appeared on "cracked and seated" section in 1997 and on "rubblized" section in 1999 (Figure 8). These cracks are more frequent in "cracked and seated" section compared to "rubblized" segment. Spaces between these cracks suggest that they are reflection cracks appearing in locations where cracking and seating and rubblization treatments may have not been completely successful in eliminating the reflection cracks observed.

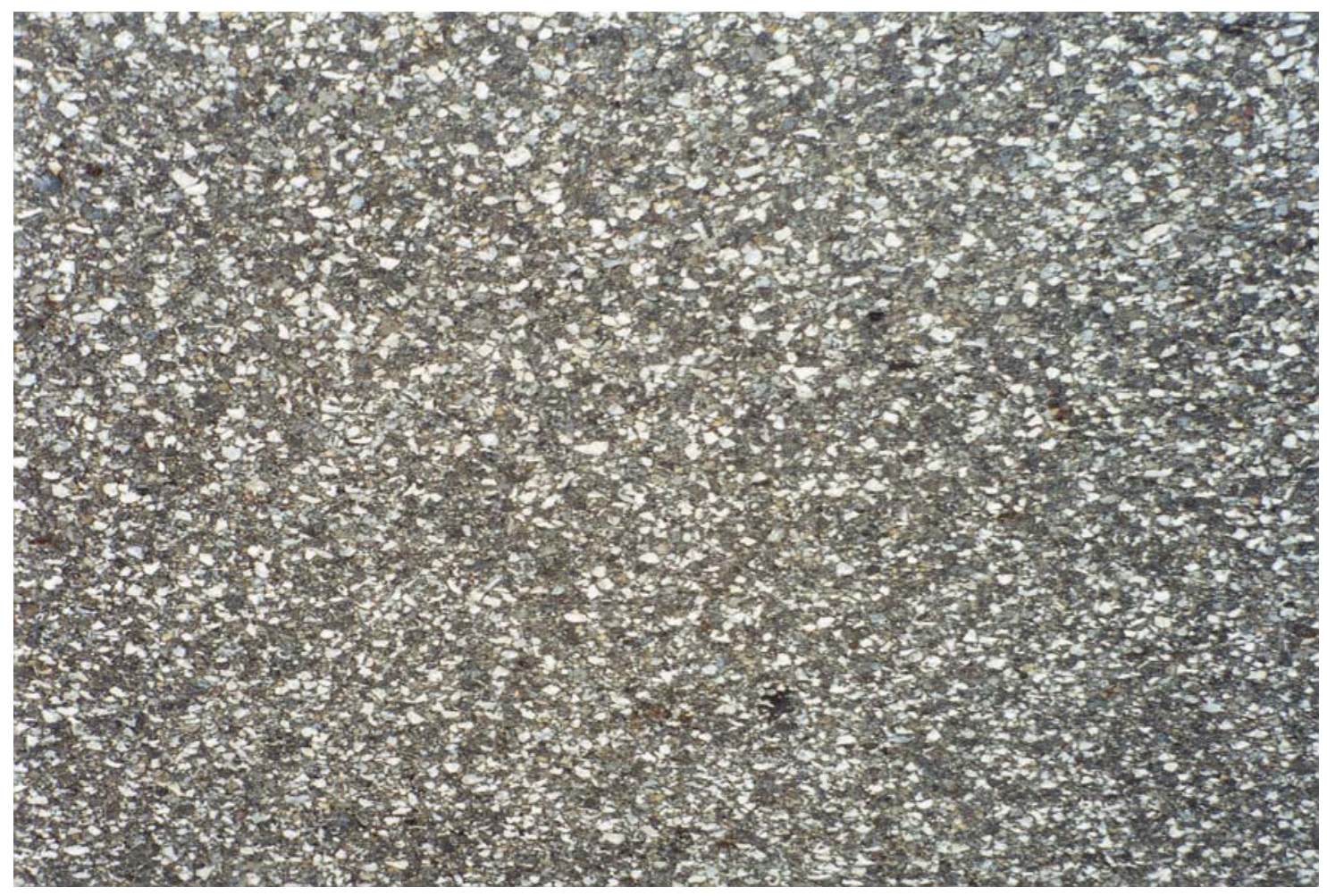

Figure 7: Raveling and Polishing Signs on "Cracked and Seated" and "Rubblized" Sections 


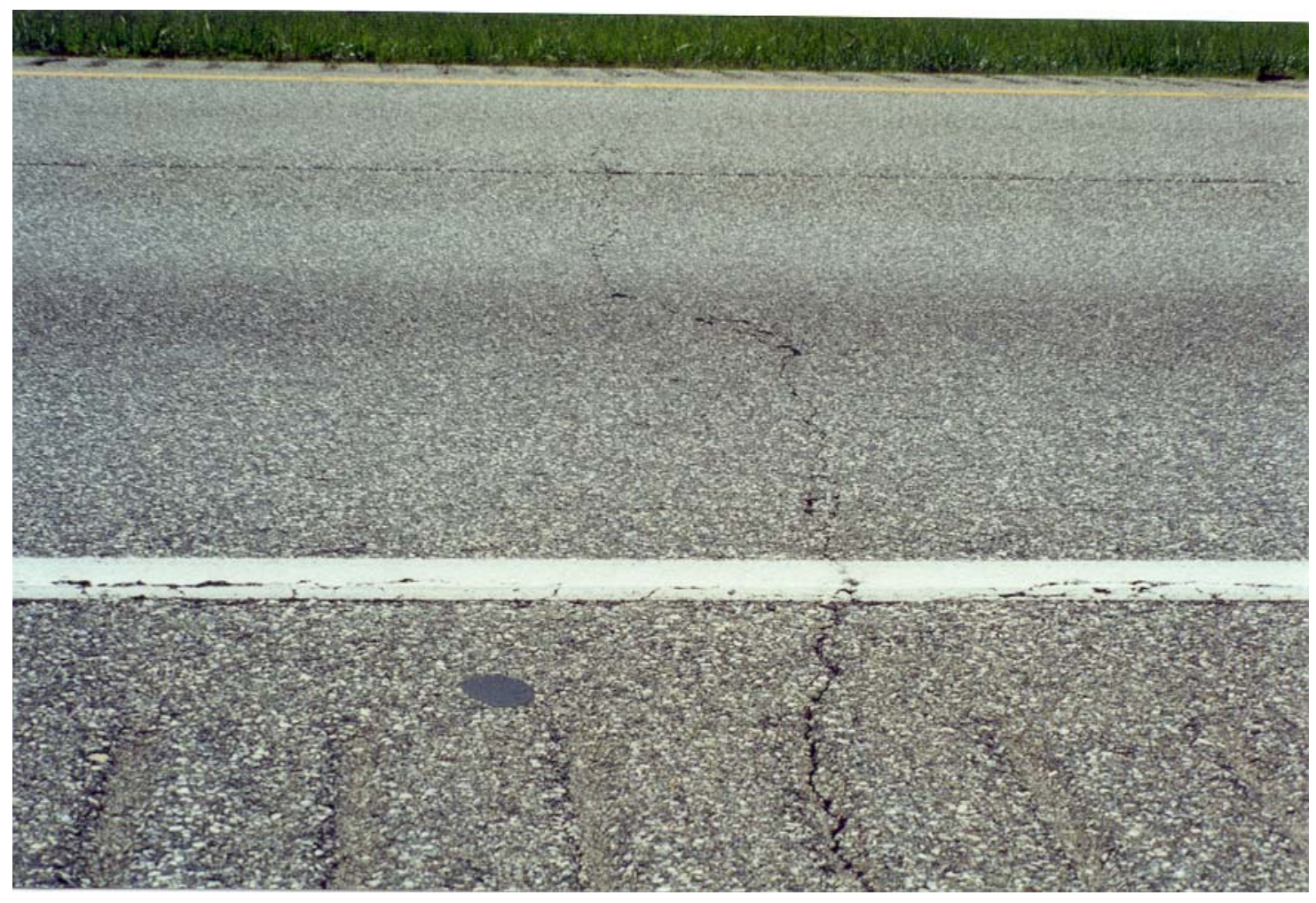

Figure 8: Full Width Transverse Cracks on "Cracked and Seated" and "Rubblized" Sections 


\section{Ride quality}

IRI data between 1994 and 1999 (Figure 9) were collected by two different contractors using two different automated data collection vehicles that collect variety of pavement data at the network level. This data suggested that the IRI value is improving with time (Figure 9) which contradicts what will be expected from any pavement segment. It is believed that the level of data accuracy for network level testing and collecting the data using two different equipment (by two different contractors) may have blocked any accuracy to show that IRI is increasing with time. In addition, pavement surface data from Interstates generally does not show significant increases in IRI for a long period of time after construction (due to their high quality in construction and structural capacity). This may have also played a role in the IRI data between 1994 and 1999.

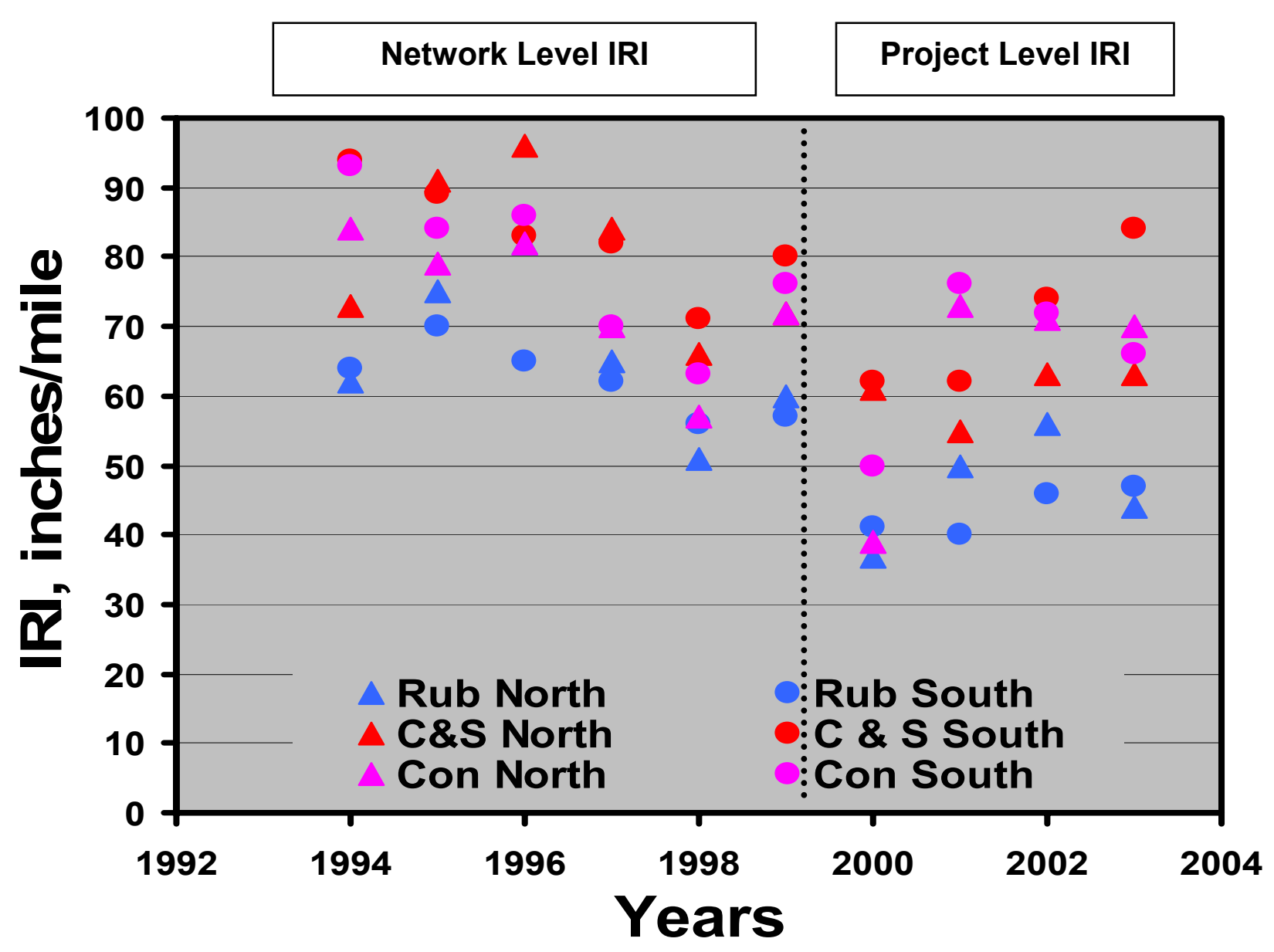

Figure 9: IRI values on I -65 rehabilitations sections from 1994 to 2003 
IRI data between the years 2000 and 2003 (Figures 9 and 10) was collected employing the calibrated and maintained IRI meter of the Research Division of INDOT. This IRI data was collected at the project level along the six rehabilitation segments only (north and south bounds). IRI values between the years 2000 and 2003 are increasing as may be expected from any pavement section. Collecting the data at the project level may have allowed obtaining a reasonable IRI trend for all sections (in the form of increase in IRI with time). The authors of this report preferred 6 years data points, as officially approved before, for the IRI in order to improve the performance predictions for accurate life cycle cost analyses. However, majority of SAC members recommended that the study be discontinued.

Although Figures 9 and 10 suggest differences in IRI means for different treatments, the analysis of variances (ANOVA) indicated that the differences are not significant by the year for all the years (1994 to 1999) in both directions as well as for the years (20002003). In addition, IRI values for all sections are less than 90 inches $/ \mathrm{mile}(1.43 \mathrm{~m} / \mathrm{km})$ which indicate a good ride quality after more than 9 years of service.

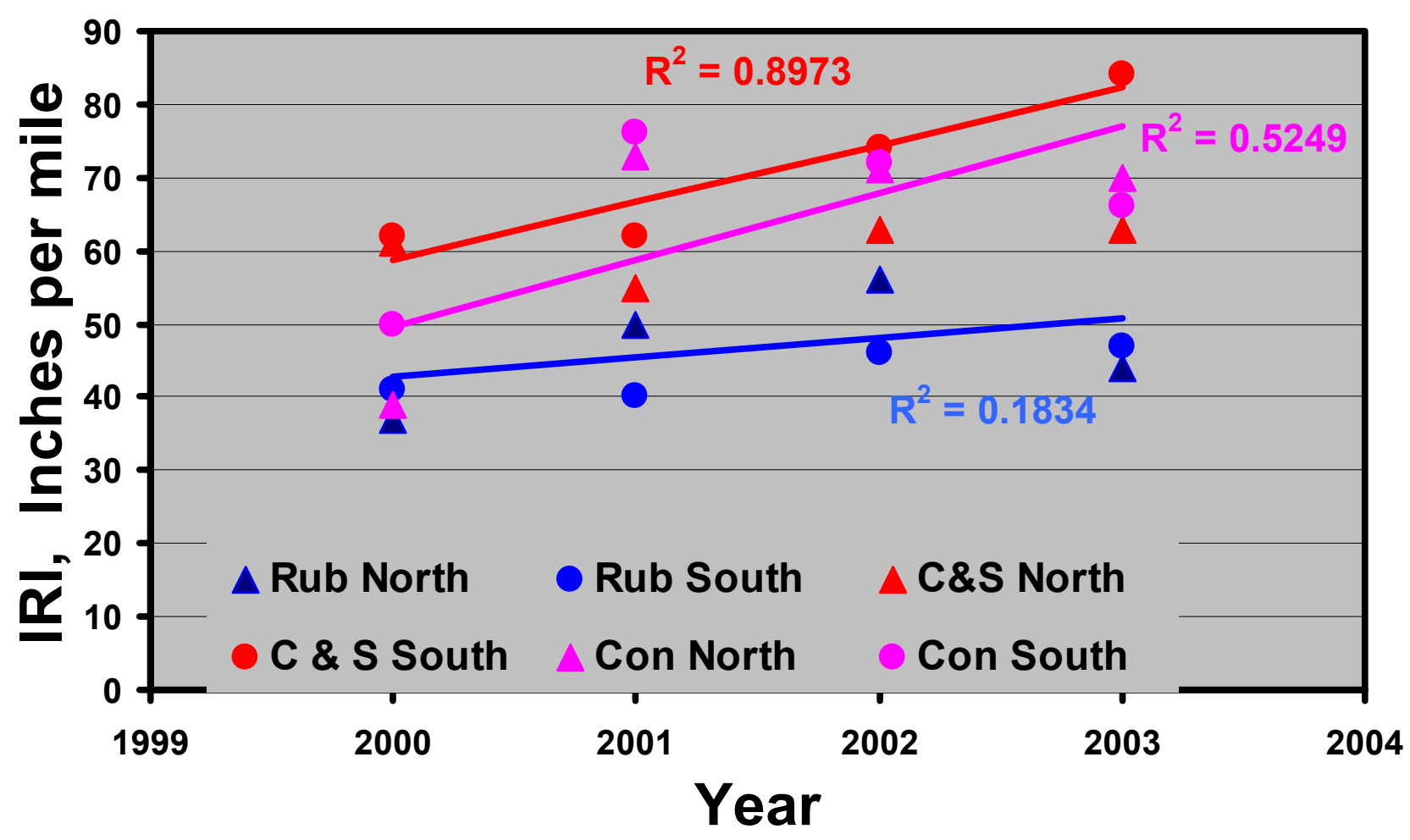

Figure 10: IRI values on I-65 Rehabilitation Sections from 2000 to 2003.

$\mathrm{CON}=$ Concrete Section

C\& $\mathbf{S}=$ Cracked and Seated Section
Rub $=$ Rubblized Section

North $=$ North Bound 
South $=$ South Bound 


\section{Friction Numbers}

Figure 11, shows the combined average friction number for the outer truck lane for both NB and SB directions after rehabilitation and annually thereafter to the year 2003. Measurements were obtained employing the method described in ASTM E-524 in which a smooth tire is used. Relatively large skid resistance values of concrete segment could be attributed to tined macro texture surface, Figure 12. Increase in friction value exhibited by the crack \& seated segment may be attributed to the progressive raveling observed on that segment.

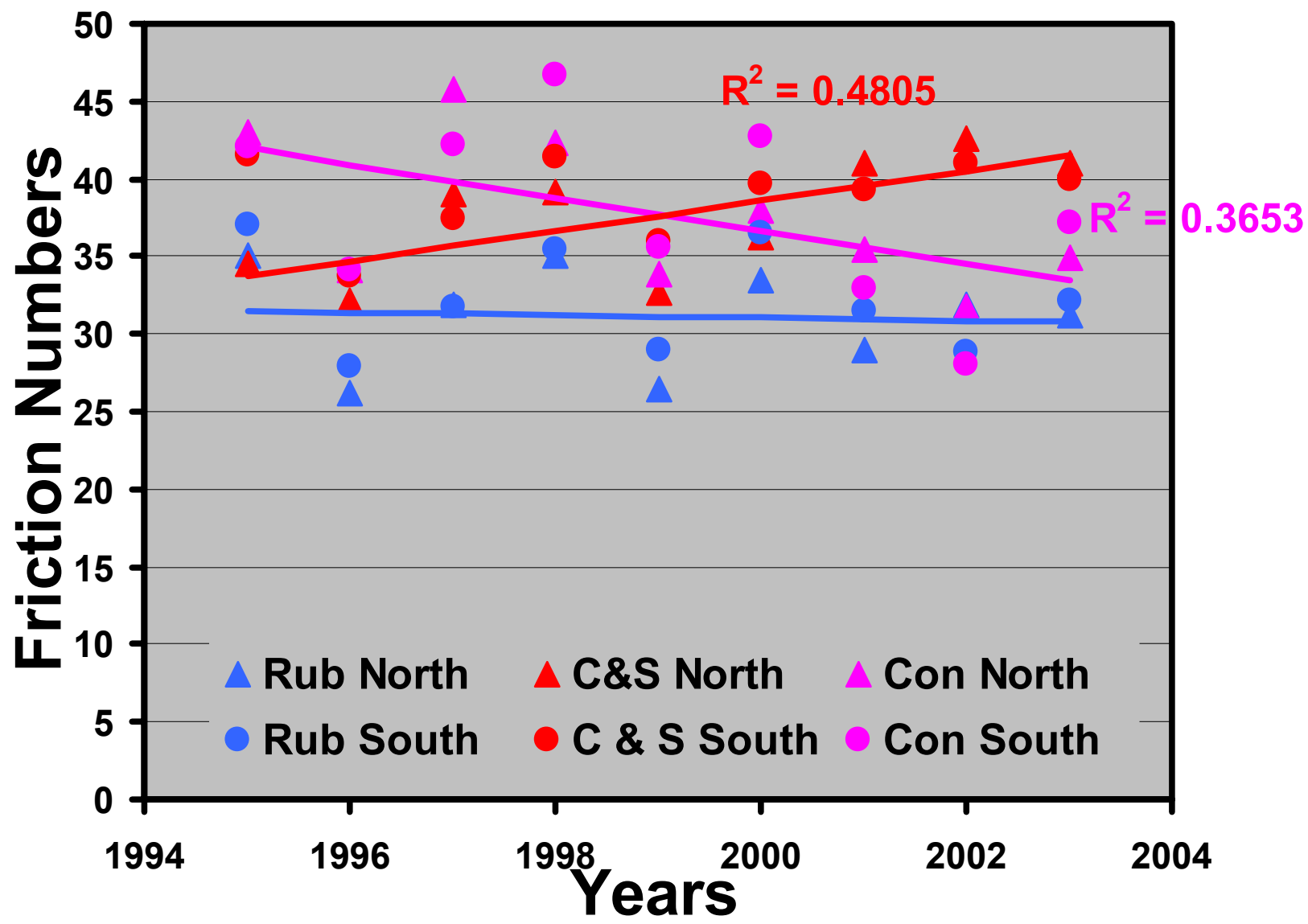

Figure 11: I-65 Friction Numbers from 1995 to 2003. 


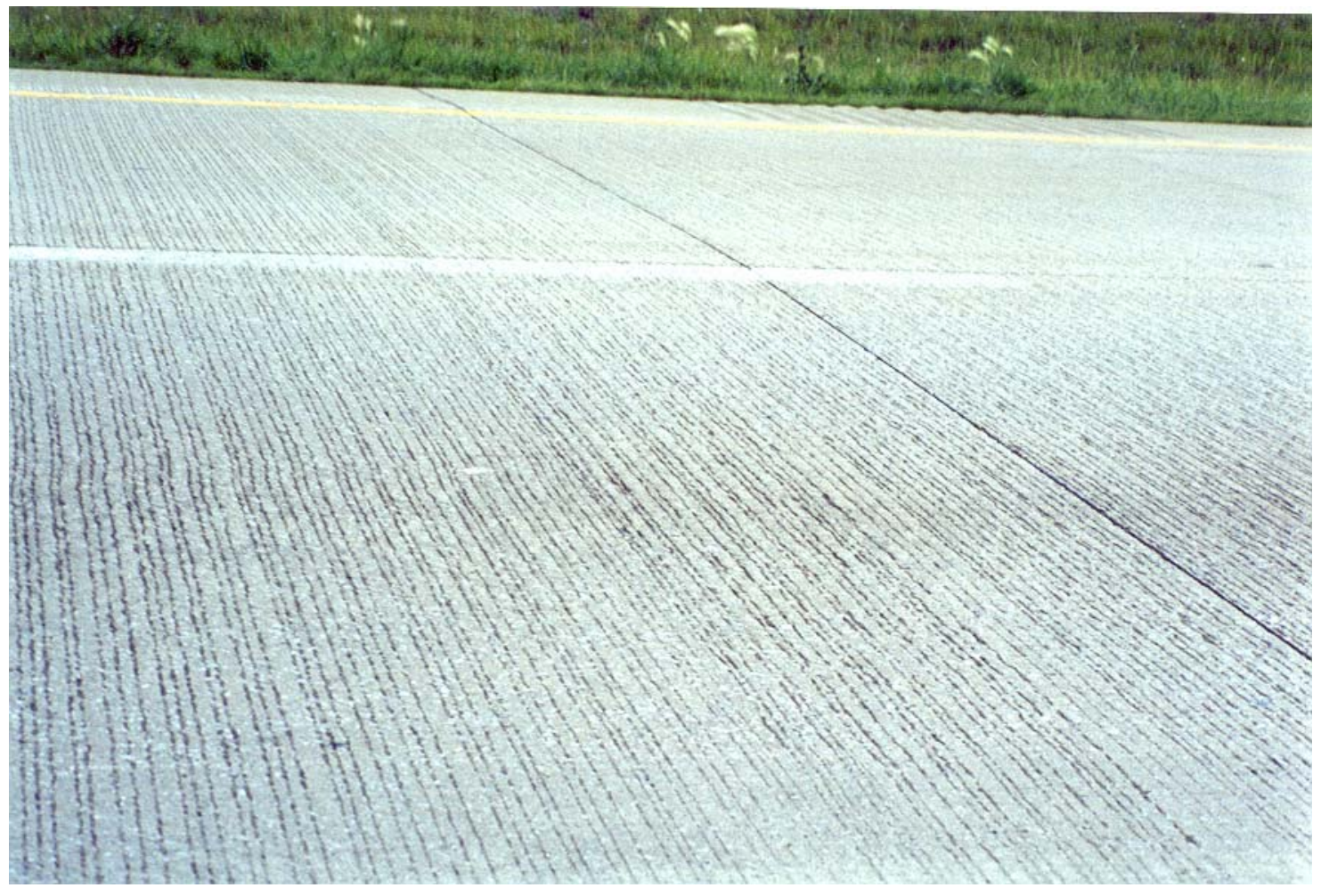

Figure 12: Concrete Surface Textures 


\section{Deflection}

Figure 13, shows the combined average FWD center deflection for the outer truck lane for both NB and SB directions after rehabilitation, and annually thereafter to the year 2002. Deflection data were normalized for a $40 \mathrm{KN}$ load (9000 pounds) and $20 \mathrm{C}(68 \mathrm{~F})$ temperature. Deflections of "Concrete" segment were not normalized for temperature. Analysis of variance, ANOVA, indicates that the deflections of the "concrete" segment are the lowest, followed by the "rubblized" and "cracked and seated" segments respectively, Figure 13. Deflection values are below 8 mils structural trigger value for major rehabilitation). Progress of deflection increase suggests that the trigger deflection value will not be reached for the concrete and rubblized sections till the year 2024, and hence major rehabilitation will not be required to improve the structural capacity (of these two sections) even after 30 years of service (or the year 2024).

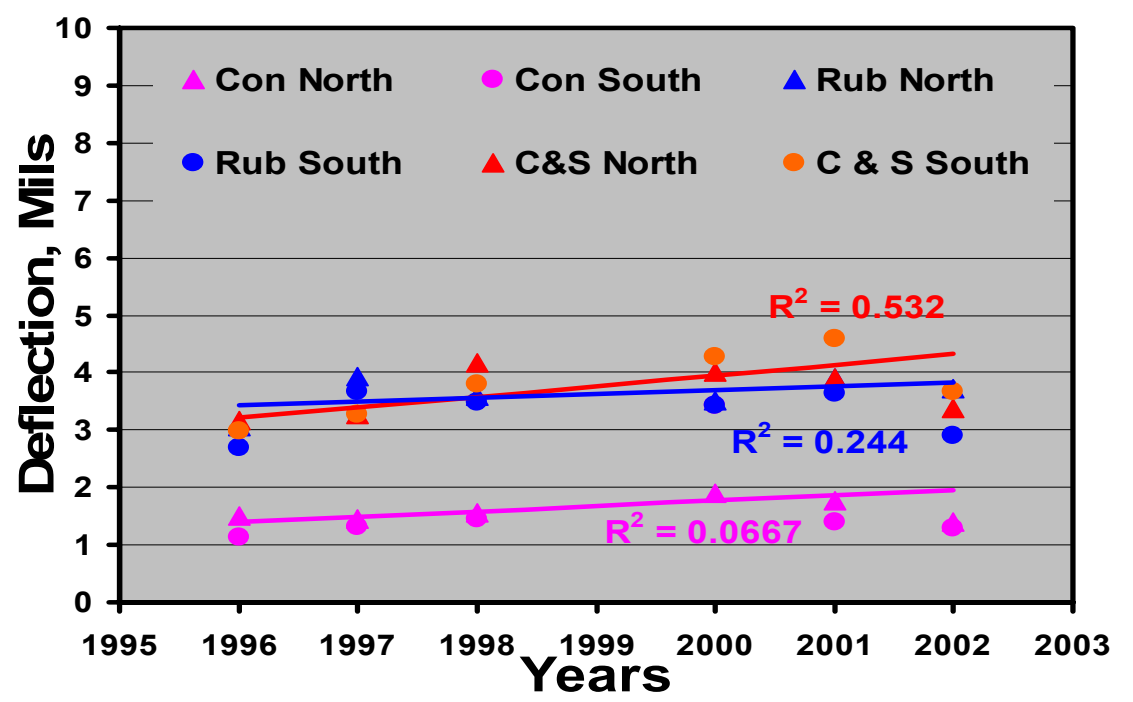

Figure 13: I-65 Deflection Values from 1996 to 2002.

\section{Uniformity of pavement performance parameters}

Table 2 presents the coefficient of variation (COV) and other related values of every performance parameter (ride quality, friction number and deflection) along the north bound study sections. Lower COV values may be indicators of uniformity. Values presented in Table 2 suggest that, IRI, Deflection and Friction values are uniform along all study sections. 
Table 2: Uniformity of Pavement Evaluation Parameters

\begin{tabular}{|c|c|c|c|c|c|c|c|c|c|c|c|c|c|c|c|c|}
\hline & \multicolumn{5}{|c|}{ Concrete Section } & \multicolumn{5}{|c|}{ Rubblized Section } & \multicolumn{5}{|c|}{ Cracked and Seated Section } \\
\hline & & 94 & 95 & 96 & 97 & 98 & 94 & 95 & 96 & 97 & 98 & 94 & 95 & 96 & 97 & 98 \\
\hline \multirow{3}{*}{$\begin{array}{l}\mathbf{I} \\
\mathbf{R} \\
\mathbf{I} \\
\end{array}$} & Mean & 1.4 & 1.29 & 1.33 & 1.10 & 0.95 & 1.32 & 1.41 & 1.41 & 1.31 & 1.13 & 1.00 & 1.14 & 1.16 & 1.00 & 0.85 \\
\hline & Std. & 0.23 & 0.08 & 0.08 & 0.08 & 0.07 & 0.24 & 0.34 & 0.31 & 0.33 & 0.26 & 0.28 & 0.23 & 0.24 & 0.24 & 0.18 \\
\hline & COV & 16 & 6 & 6 & 7 & 7 & 18 & 24 & 22 & 25 & 23 & 28 & 20 & 21 & 24 & 21 \\
\hline \multirow{3}{*}{$\begin{array}{l}\text { D } \\
\text { E } \\
\text { F } \\
\end{array}$} & Mean & & & 33.4 & 35.3 & 38.1 & & & 52.2 & 68.9 & 64.3 & & & 55.8 & $\overline{59.1}$ & 72.2 \\
\hline & Std. & & & 14.2 & 9.6 & 10.8 & & & 3.4 & 5.5 & 5.9 & & & 9.03 & 20.8 & 16.6 \\
\hline & $\mathrm{COV}$ & & & 43 & 27 & 28 & & & 7 & 8 & 9 & & & 16 & 35 & 23 \\
\hline \multirow[t]{3}{*}{$\mathbf{F}$} & Mean & & 41.5 & 34 & 44 & 45 & & 36 & 27 & 32 & 35 & & 39 & 33 & 44 & 40 \\
\hline & Std. & & 3.6 & 5.8 & 4.6 & 4.7 & & 5.0 & 3.9 & 5.6 & 2.4 & & 2.1 & 4.6 & 4.6 & 3.1 \\
\hline & COV & & 9 & 17 & 10 & 11 & & 14 & 14 & 17 & 7 & & 5 & 14 & 10 & $8 \%$ \\
\hline
\end{tabular}

Std. $=$ Standard Deviation

$\mathrm{COV}=$ Coefficient of variation $=$ mean $/$ std. $* 100$

$\mathrm{DEF}=$ Deflection in microns; 1 mill $=25.4$ micron

$\mathrm{FN}=$ Friction number $=100 *$ Coefficient of Friction.

IRI = International Roughness Index in $\mathrm{m} / \mathrm{km}$. 


\section{LIFE CYCLE COST ANALYSIS}

The detailed information, including initial and follow up maintenance costs, of the three rehabilitation techniques are given in Table 3.

Table 4 presents the present worth (PW) of total life cycle cost for the three rehabilitation strategies investigated. Costs of HMA overlays without slab fracturing techniques, together with concrete pavement restoration (CPR) are also presented for comparison purposes. Cost information is based on the following assumptions:

- A 30 year analysis period and 5\% discount rate.

- Salvage values and rehabilitation costs at the end of analysis period are not included and assumed to be identical for all rehabilitation strategies.

- Routine maintenance and other miscellaneous costs are not included and assumed to be identical for all rehabilitation strategies.

- Road user's costs and costs associated with the period of time during which the facility is shut down are also not included.

- Marginal effect of inflation.

- Milling and resurfacing will be required for "rubblized" segment in the years 2004 and 2014.

- Overlay will be required for the "cracking and seating" segment in the year 2004 to increase pavement thickness to the level of other segments.

Total life cycle costs presented in Table 4 suggests that the "concrete" segment is the most cost effective. However, based on practice and guidelines of the other states source (such as Minnesota and Ohio) life cycle cost within $10 \%$ differences is too close to call. Any slight change in the cost analysis assumptions may, very easily, "reverse that call". In many circumstances the pavement design engineer faces this dilemma in which there is no clear-cut answer about the most cost effective rehabilitation strategy. Presence of good engineering judgment is required for those circumstances. As an example, for the investigation presented herein, employing concrete pavement restoration again can not be considered an alternative because of the need for adding additional structural capacity for the pavement to sustain future traffic. 
Table 3: Construction Cost Data of the three Rehabilitation Techniques on I-65

\begin{tabular}{|c|c|c|c|c||}
\hline $\begin{array}{c}\text { REHABILITATION } \\
\text { (OVERLAYS) }\end{array}$ & $\begin{array}{c}\text { YEAR } \\
\text { OPENED }\end{array}$ & $\begin{array}{c}\text { COST } \\
\text { PER MILE } \\
\text { (Two-lanes \& } \\
\text { Shoulders) }\end{array}$ & $\begin{array}{c}\text { REFERENCE } \\
\text { POST }\end{array}$ \\
FROM & TO \\
\hline \hline $\begin{array}{c}\text { Unbonded Concrete Overlay over the } \\
\text { existing old concrete pavement } \\
\text { 10.0 km. (6,2 mi.) long }\end{array}$ & July 1993 N & $\$ 239,800$ & 217.2 & 223.4 \\
October 1993 S & $\$ 239,800$ & 223.4 & 217.2 \\
$\begin{array}{c}\text { HMA Overlay over Rubblized existing old } \\
\text { concrete pavement }\end{array}$ & October 1994 N & $\$ 236,000+17.2 \mathrm{~K}^{*}$ & 223.4 & 229.1 \\
9.2 km. (5.7 mi.) long & July 1994 S & $\$ 236,000+17.2 \mathrm{~K}^{*}$ & 229.1 & 223.4 \\
\hline Fiber-Reinforced HMA Overlay over the & July 1993 N & $\$ 180,500+17.2 \mathrm{~K}^{*}$ & 229.1 & 234.0 \\
Cracked and Seated old concrete pavement & Nov. 1994 N & $\$ 180,500+17.2 \mathrm{~K}^{*}$ & 234.0 & 237.8 \\
14 km. (8.7 mi.) long & Nov. 1993 S & $\$ 180,500+17.2 \mathrm{~K}^{*}$ & 237.8 & 234.0 \\
& August 1993 S & $\$ 180,500+17.2 \mathrm{~K}^{*}$ & 234.0 & 229.1 \\
\hline \hline
\end{tabular}

* The cracks on the Cracked \& Seated section and on the Rubblized Section were sealed in the fall of 2000 under the contract M-25193. The total cost was $\$ 246,470$ ( $\$ 17,116$ per mile). 
Table 4: Present Worth of Cost of Various Concrete Pavements Rehabilitation Strategies

\begin{tabular}{|c|c|c|c|c|c|}
\hline \multicolumn{2}{|c|}{ "Concrete" Segment } & \multicolumn{2}{|c|}{ "Rubblized" Segment } & \multicolumn{2}{|c|}{ "Cracking and Seating" Segment } \\
\hline $\begin{array}{l}\text { Activity and } \\
\text { Year }\end{array}$ & $\begin{array}{l}\text { Cost per lane } \\
\text { kilometer }\end{array}$ & $\begin{array}{l}\text { Activity and } \\
\text { Year }\end{array}$ & $\begin{array}{l}\text { Cost per lane } \\
\text { kilometer }\end{array}$ & $\begin{array}{l}\text { Activity and } \\
\text { Year }\end{array}$ & $\begin{array}{l}\text { Cost per lane } \\
\text { kilometer }\end{array}$ \\
\hline $\begin{array}{l}\text { HMA Leveling } \\
\text { Course, } 1994\end{array}$ & $\$ \quad 6,600$ & $\begin{array}{l}\text { Rubblization, } \\
1994\end{array}$ & $\$ \quad 10,000$ & $\begin{array}{l}\text { Cracking \& } \\
\text { Seating, } 1994\end{array}$ & $\$ \quad 8,000$ \\
\hline $\begin{array}{l}\text { Construction, } \\
1994\end{array}$ & $\$ 110,000$ & $\begin{array}{l}\text { Construction, } \\
1994\end{array}$ & $\$ \quad 86,000$ & $\begin{array}{l}\text { Construction, } \\
1994\end{array}$ & $\$ 75,000$ \\
\hline & & $\begin{array}{l}\text { Milling, } \\
2004\end{array}$ & $\$ \quad 5,000$ & $\begin{array}{l}140 \mathrm{~mm} \\
\text { Overlay, } 2004\end{array}$ & $\$ 29,100$ \\
\hline & & $\begin{array}{l}40 \mathrm{~mm} \\
\text { Resurfacing, } \\
2004\end{array}$ & $\$ \quad 8,300$ & $\begin{array}{l}\text { Milling, } \\
2014\end{array}$ & $\$ 3,100$ \\
\hline & & $\begin{array}{l}\text { Milling, } \\
2014\end{array}$ & $\$ \quad 3,100$ & $\begin{array}{l}40 \mathrm{~mm} \\
\text { Resurfacing, } \\
2014\end{array}$ & 5,100 \\
\hline & & $\begin{array}{l}40 \mathrm{~mm} \\
\text { Resurfacing, } \\
2014\end{array}$ & $\$ \quad 5,100$ & & \\
\hline Total & $\$ 116,600$ & Total & $\$ 117,500$ & Total & $\$ 120,300$ \\
\hline
\end{tabular}

\begin{tabular}{|l|rc|l|c|}
\hline \multicolumn{2}{|c|}{ HMA Overlays Without Slab Fracturing Techniques } & \multicolumn{2}{|c|}{ Concrete Pavement Restoration } \\
\hline Activity and Year & Cost per lane kilometer & Activity and Year & Cost per lane kilometer \\
\hline \hline $190 \mathrm{~mm}$ Overlay, 1994 & $\$ 49,500$ & CPR, 1994 & $\$ 37,400$ \\
\hline Milling, 2004 & $\$ 5,000$ & CPR, 2000 & $\$ 32,300$ \\
\hline $190 \mathrm{~mm}$ Overlay, 2004 & $\$ 38,800$ & CPR, 2006 & $\$ 23,000$ \\
\hline Milling 2014 & $\$ \quad 3,100$ & CPR, 2012 & $\$ 16,400$ \\
\hline $190 \mathrm{~mm}$ Overlay, 2014 & $\$ 23,800$ & CPR, 2018 & $\$ 11,700$ \\
\hline Total & $\$ 120,200$ & Total & $\$ 120,800$ \\
\hline
\end{tabular}




\section{FINDINGS AND CONCLUSIONS}

The main objective of the study presented in this report is to evaluate the performance of three concrete pavement rehabilitation strategies on interstate highway I - 65;

a) Unbonded concrete overlay over the existing old concrete pavement with an open graded HMA layer placed between the overlay and the existing old concrete pavement.

b) HMA overlay on the rubblized existing old concrete pavement.

c) Fiber Reinforced HMA Overlay on the cracked and seated existing old concrete pavement.

Life cycle costs analyses of these rehabilitation strategies were evaluated and compared with that of concrete pavement restoration (CRP) techniques applied at a previous date on the same highway segment in 1985.

These rehabilitation techniques were employed on a $33 \mathrm{~km}$ (20.6 miles) portion of jointed reinforced concrete pavement on I-65 between reference posts 217.2 and 237.8 in Indiana.

Findings and conclusions of this research study should not be statistically generalized to cover all other similar overlays. The main findings and conclusions (which may be limited to the conditions presented in this study) can be summarized as follows:

1. Unbonded concrete overlay is a very effective rehabilitation technique for eliminating reflection cracks.

2. Rubblization is an effective rehabilitation technique for minimizing and delaying reflection cracks if constructed successfully.

3. The 1993 cracking and seating technique (as used here on I-65) is not recommended. This technique has already been improved.

4. Annual visual condition surveys suggest that "concrete" segment has better performance than the "rubblized" and "cracked and seated" segments.

5. Annual ride quality and skid resistance values of all overlays are statistically equal.

6. Annual FWD deflection measurements suggest that "concrete" segment has lower deflection compared to the "rubblized" and "cracked and seated" segments.

7. Life cycle cost analysis suggests that "concrete" segment is the most cost effective followed by "rubblized" and "cracked and seated" segments, respectively. However, this is a very close call. 
8. Visual inspections of the three overlay techniques in the last 5 years indicated that there are visible cracks in the "Rubblized" and "Cracking and seating" segments and they were scheduled for crack sealing operations and sealed in the 2000 construction season. 


\section{IMPLEMENTATION}

Based on this long term research study, the findings should be implemented by the Materials and Tests Division and the Research Division of INDOT.

Unbonded concrete overlays are a viable rehabilitation technique which should be employed on appropriate highway sections.

Rubblized treatment is preferred over Cracked \& Seated treatment.

As a part of implementation, annual field inspection is strongly recommended since this is a long term research study as per the Chief Highway Engineer, Richard K. Smutzer. An evaluation period of 20 years after construction is recommended and a proper report should also be written afterward. A more meaningful life-cycle cost can be assessed to each section at that time.

It is also recommended that visual inspection, IRI and Friction values should also be obtained employing the Research Division's equipment and staff. 


\section{REFERENCES}

1. E. D. Moody, “Field Investigation of Selected Strategies to Reduce Reflective Cracking in Asphalt Concrete Overlays Constructed Over Existing Jointed Concrete Pavements ", in Transportation Research Record TRR 1449, Transportation Research Board, National Research Council, Washington, D.C., 1994.

2. Snyder, M. B., Reiter, M. J., Hall, K. T., and M. I. Darter " Rehabilitation of Concrete Pavements, Volume I - Repair Rehabilitation Techniques " Report Number FHWA - RD 88 - 071, Federal Highway Administration, 1989.

3. Voigt, G. F., Carpenter, S. H., and M. I. Darter " Rehabilitation of Concrete Pavements, Volume II - Overlay Rehabilitation Techniques " Report Number FHWA - RD - 88 - 072, Federal Highway Administration, 1989.

4. Hallin, J. P., Mathis, D. M., and R. L. Lee, “ Performance Review of Concrete Pavement Restoration " in Transportation Research Record TRR1186, Transportation Research Board, National Research Council, Washington, D.C., 1988.

5. FHWA, "Portland Cement Concrete Pavement Restoration", Demonstration Project 69, Federal Highway Administration, U.S. Department of Transportation, 1984.

6. Noureldin, A. S., and R. S. McDaniel, "Evaluation of Concrete Pavement Restoration Techniques on I - 65" in Transportation Research Record, TRR 1215, Transportation Research Board, National Research Council, Washington, D.C., 1989.

7. Jiang, Y., and R. S. McDaniel, "Application of Cracking and Seating and Use of Fibers to Control Reflective Cracking", in Transportation Research Record, TRR 1388, Transportation Research Board, National Research Council, Washington, D. C., 1993.

8. Trezos, K., and S. Gulen, "Correlation of Roadmeter Roughness Number with P.S.I., Final Report, Division of Research, INDOT, 1982.

9. AASHTO, "AASHTO Guide for Design of Pavement Structures", American Association of state Highway and Transportation Officials, 1993.

10. Gulen, S., Woods, R., Weaver, J., and V. L. Anderson, "Correlation of Present Serviceability Ratings with International Roughness Index", in Transportation Research Record TRR 1435, Transportation Research Board, National Research Council, Washington, D.C., 1994. 